Nguyen Thi Thuy Dung,

PhD., in Management Psychology, associate professor,

Saigon University, Vietnam

Email: thuydung139@gmail.com

\title{
A SURVEY ON THE AFFECTING FACTORS ON THE MANAGEMENT OF CHANGES IN KINDERGARTENS AND SCHOOLS IN HO CHI MINH CITY, VIETNAM
}

\begin{abstract}
The article presents the results of survey on the affecting factors on the management of changes by principals in kindergartens and schools in Ho Chi Minh City. The survey has been conducted by means of in-depth interviews and questionnaires among 177 principals and 1829 viceprincipals, subject division heads, teachers and staffs in kindergartens, primary and secondary schools in Ho Chi Minh City. The survey has determined 10 internal and 4 external factors affecting the change management in schools, the most affecting factor of which belongs to principals. The results show that the principals' awareness and attitude of change awareness, as well as their competencies and prestige are the most affecting factors.
\end{abstract}

Keywords: affecting factors, managing; changes; kindergartens; schools; Ho Chi Minh City.

\section{Introduction}

Ho Chi Minh City is a large city - the center of economy, culture, education and training, science and technology of Vietnam, the place where changes have been taken place very rapidly and continuously. Since the Eighth Plenum of the Central Committee of the Communist Party of Vietnam (XI) (2013) issued "The resolution on the basic and comprehensive renovation of education and training" and the Prime Minister of Vietnam (2012) issued "Vietnam Education Development Strategy in the period of 20112020 ", together with the whole country, the education of Ho Chi Minh City has carried out the basic and comprehensive renovation. This makes schools and kindergartens in Ho Chi Minh City face urgent and continuous changes in all fields. These changes need to be scientifically managed by principals.

The article presents the results of the survey on the affecting factors on the management of changes by principals in kindergartens and schools in $\mathrm{Ho}$ Chi Minh City, which helps to explain reasons for the suc- cess and failure in the management of changes in order to propose some solutions to assist principals in successfully managing changes and contribute to the success of education innovation in Ho Chi Minh City.

\section{Literature review}

Results of researches of some authors in the world and in Vietnam show that there are many factors affecting the management of changes of an organization, such as: the prestige of leaders (David M. Herold \& Donald B. Fedor [2, P. 87]); the attitude of group's members (the authors of Harvard University [3, P. 90-91]); the organization culture (David M. Herold \& Donald B. Fedor [2, P. 185]); factors of leaders - the subject of the management of changes (Nguyen Thi Bich Dao [4, P. 159-166]); personalities and skills of leaders (Nguyen Thi Thuy Dung [5, P. 5-7]); contexts of economy, politics, culture and society; the coordination of students parents and the coordination of the local authorities (Vietnam Academy of Education Management' textbook for high school managers [7, P. 124]); .. 
The results of the literature review allow to divide affecting factors on managing changes in kindergartens and schools into 2 groups:

- Internal factors, including: 1) Factors of principals; 2) Factors of education staffs; 3) Factors of the environment and working condition.

- External factors, including: 1) Context of economy, politics, culture and society; 2) Directions of the authorities; 3 ) The coordination of students' parents; 4) The coordination of the local authorities.

\section{Overview of the survey}

\subsection{Goal and content of the survey}

Based on the above theoretical statements, the goal of the survey is to clarify the facts of affecting factors on the principal's change management in Ho Chi Minh City kindergartens and schools.

The content of the survey includes: $1 /$ The affecting level of internal factors; 2 / The affecting level of external factors.

\subsection{Area of the survey, the surveyed objects and the methodology}

* Area of the survey:

The survey is conducted in 7 districts in Ho Chi Minh City (District 3, 6, 8, Phu Nhuan, Binh Thanh, Tan Binh, Tan Phu).

* The surveyed objects:

The survey samples include 2006 persons of the overall target (Table 1):

Table 1.- The survey samples

\begin{tabular}{|l|c|c|c|c|}
\hline \multicolumn{1}{|c|}{ Positions } & Kinder-gartens & Primary schools & Secondary schools & Total \\
\hline Principals & 65 & 52 & 60 & 177 \\
\hline Vice-principals & 54 & 35 & 40 & 129 \\
\hline Subject division-heads & 96 & 101 & 102 & 299 \\
\hline Teachers & 427 & 284 & 431 & 1142 \\
\hline Staffs Total & 69 & 95 & 95 & 259 \\
\hline \multicolumn{1}{|c|}{ Tot } & 567 & 728 & $\mathbf{2 0 0 6}$ \\
\hline
\end{tabular}

* The methodology:

The survey combines the methodology of the questionnaire and in-depth interviews.

- The questionnaire is for 2006 surveyed objects, which requires their evaluation on the affecting level of the factors by means of the grading scheme: 5 points - strongly affected, 4 points - quite affected, 3 points - affected, 2 points - slightly affected, 1 point - unaffected.

The average point is divided into the levels: 1 point -1.80 points: unaffected; 1.81 points -2.60 points: slightly affected; 2.61 points -3.40 points: affected; 3.41 points -4.20 points: quite affected; 4.21 points -5 points: strongly affected.

- The in-depth interviews are conducted to clarify countable results collected from the methodology of questionnaire: 1) In-depth interviews with 21 principals ( 7 Kindergarten principals, 7 Primary school principals, 7 Secondary school principals). Personal identity of participants is encoded as: Kindergarten principal no.1 (KGP1) to Kindergarten principal no.7 (KGP7); Primary school principal no.1 (PSP1) to Primary school principal no. 7 (PSP7); Secondary school principal no.1 (SSP1) to Secondary school principal no.7 (SSP7). 2) In-depth interviews with 21 teachers (7 Kindergarten teachers, 7 Primary school teachers, 7 Secondary school teachers). Personal identity of participants is encoded as: Kindergarten teacher no. 1 (KGT1) to Kindergarten teacher no. 7 (KGT7); Primary school teacher no.1 (PST1) to Primary school teacher no. 7 (PST7); Secondary school teacher no.1 (SST1) to Secondary school teacher no. 7 (SST7).

\section{Results of the survey}

4.1. The affecting levels of the internal factors 
Table 2. - The affecting level of the internal factors according to the assessment of the principals, education staffs in kindergartens, primary and secondary schools

\begin{tabular}{|c|c|c|c|c|c|c|c|c|c|}
\hline \multirow[b]{2}{*}{ No. } & \multirow[b]{2}{*}{ Internal factors } & \multicolumn{2}{|c|}{$\begin{array}{c}\text { Kinder-gar- } \\
\text { tens }\end{array}$} & \multicolumn{2}{|c|}{$\begin{array}{l}\text { Primary } \\
\text { schools }\end{array}$} & \multicolumn{2}{|c|}{$\begin{array}{c}\text { Secondary } \\
\text { schools }\end{array}$} & \multicolumn{2}{|c|}{ Total } \\
\hline & & $\begin{array}{c}\text { Point } \\
\text { Aver- } \\
\text { age }\end{array}$ & Rank & $\begin{array}{c}\text { Point } \\
\text { Aver- } \\
\text { age }\end{array}$ & Rank & $\begin{array}{c}\text { Point } \\
\text { Aver- } \\
\text { age }\end{array}$ & Rank & $\begin{array}{c}\text { Point } \\
\text { Aver- } \\
\text { age }\end{array}$ & Rank \\
\hline \multicolumn{10}{|c|}{ Factors of the school principals } \\
\hline 1. & $\begin{array}{l}\text { The attitude of school principals to- } \\
\text { wards changes }\end{array}$ & 4.35 & 2 & 4.32 & 4 & 4.35 & 1 & 4.34 & 2 \\
\hline 2. & $\begin{array}{l}\text { The school principal awareness of the } \\
\text { importance of managing changes }\end{array}$ & 4.27 & 6 & 4.33 & 3 & 4.27 & 4 & 4.28 & 4 \\
\hline 3. & $\begin{array}{l}\text { The ability of school principals in } \\
\text { managing changes }\end{array}$ & 4.33 & 3 & 4.37 & 1 & 4.34 & 2 & 4.35 & 1 \\
\hline 4. & $\begin{array}{l}\text { The prestige of the principals in } \\
\text { schools }\end{array}$ & 4.38 & 1 & 4.33 & 2 & 4.31 & 3 & 4.34 & 2 \\
\hline & General & 4.33 & & 4.34 & & 4.32 & & 4.33 & 1 \\
\hline \multicolumn{10}{|c|}{ Factors of Education staffs } \\
\hline 5. & $\begin{array}{l}\text { The attitude of education staffs to- } \\
\text { wards changes }\end{array}$ & 4.25 & 7 & 4.20 & 9 & 4.19 & 8 & 4.21 & 9 \\
\hline 6. & $\begin{array}{l}\text { The ability of education staffs to per- } \\
\text { form tasks }\end{array}$ & 4.27 & 5 & 4.22 & 7 & 4.17 & 10 & 4.22 & 8 \\
\hline 7. & $\begin{array}{l}\text { The quality and common sense of } \\
\text { education staffs }\end{array}$ & 4.31 & 4 & 4.24 & 6 & 4.24 & 5 & 4.27 & 5 \\
\hline & General & 4.28 & & 4.22 & & 4.20 & & 4.23 & 2 \\
\hline \multicolumn{10}{|c|}{$\begin{array}{l}\text { Factors of environment and working } \\
\text { conditions }\end{array}$} \\
\hline 8. & The school culture & 4.22 & 10 & 4.18 & 11 & 4.15 & 11 & 4.19 & 10 \\
\hline 9. & $\begin{array}{l}\text { The activities of Communist Party } \\
\text { and other associations }\end{array}$ & 4.18 & 12 & 4.19 & 10 & 4.17 & 9 & 4.18 & 11 \\
\hline 10. & The financial conditions and facilities & 4.23 & 9 & 4.21 & 8 & 4.24 & 5 & 4.23 & 6 \\
\hline & General & 4.21 & & 4.20 & & 4.19 & & 4.20 & 3 \\
\hline & $\begin{array}{l}\text { erall assessment of the internal fac- } \\
\text { tors }\end{array}$ & 4.27 & & 4.25 & & 4.24 & & 4.25 & \\
\hline
\end{tabular}

a) The affecting level of the factors of principals

Data from Table 2 show that all 4 factors of principals are evaluated by surveyed objects in all 3 education levels as "Strongly affected" (Lowest average point is 4.27 points and the highest is 4.38 points; general average point is 4.33 ). These 4 factors account for the 4 highest levels in grading level of school's internal factors which affect the management of changes.
The interviewed principals all agree on the high affecting level of the factors of principals. Kindergarten Principal no.1 states that: "School managers are easy to adapt and accept new things, so they manage well the changes"; Primary school Principal no. 5 states that: "Principals' competency and reputation help them to easily persuade the group to conduct innovation and manage the execution well". 
In-depth interviews with teachers also give the same results. Secondary school teacher no. 2 says that: "Principals know clearly execution process, so they manage well the management of changes in schools". As the result, the factor of attitude, competency, and prestige of management officers is the objective factor, directly affecting their management of changes.

b) The influence of the factors of education staffs

All three surveyed groups assess the level of "Strongly affected" for the factor of "Quality and common sense of education staffs" (over 4.21 points).

The in-depth interviews show that the majority of principals and teachers agree on this factor. Kindergarten Principal no. 3 thinks: "Implementing innovation in schools always has difficulties, obstacles in terms of financial conditions and facilities, and also requires a lot of new knowledge and skills, etc. Teachers of high sense of responsibility will not mind hard work". Secondary school teacher no.4 says that: "Love, responsibility and common sense will help teachers overcome difficulties in approaching, learning and implementing the innovation".

c) The influence of the factors of the working environment and conditions

Statistics in (Table 2) show that the factor "The financial conditions and facilities" is assessed at the level "Strongly affected" by kindergarten, primary and secondary school groups of the average points of 4.23, 4.21 and 4.24 respectively.

Through the in-depth interviews, $19 / 21$ principals and 16/21 teachers affirm that "The financial conditions and facilities" has influence on the management of school changes. "Although the financial sources for making innovation, the working conditions and facilities are the external factors, they have great effects on the management because they can make working motivation for education staffs", Primary school principal no. 2 says.

"The activities of Communist Party and other associations" factor is evaluated as "Quite affected" by the three groups of kindergarten, primary and secondary school with the average points $4.18,4.19$, 4.17 respectively.

The surveyed groups of primary and secondary schools consider "the school culture" at "Quite affected" level. This factor could cause both advantages and disadvantages to the management of changes in schools.

"Strongly affected" is the overall assessment of the internal factors of three surveyed groups with the general average point of 4.25 .

\subsection{The affecting levels of the external factors}

Table 3. - The affecting level of the external factors according to the assessment of the principals, education staffs in kindergartens, primary and secondary schools

\begin{tabular}{|c|c|c|c|c|c|c|c|c|c|}
\hline \multirow[b]{2}{*}{ No. } & \multirow[b]{2}{*}{ External factors } & \multicolumn{2}{|c|}{$\begin{array}{l}\text { Kinder- } \\
\text { gartens }\end{array}$} & \multicolumn{2}{|c|}{$\begin{array}{l}\text { Primary } \\
\text { schools }\end{array}$} & \multicolumn{2}{|c|}{$\begin{array}{c}\text { Secondary } \\
\text { schools }\end{array}$} & \multicolumn{2}{|c|}{ Total } \\
\hline & & $\begin{array}{c}\text { Point } \\
\text { Aver- } \\
\text { age }\end{array}$ & Rank & $\begin{array}{c}\text { Point } \\
\text { Aver- } \\
\text { age }\end{array}$ & Rank & $\begin{array}{c}\text { Point } \\
\text { Aver- } \\
\text { age }\end{array}$ & Rank & $\begin{array}{c}\text { Point } \\
\text { Aver- } \\
\text { age }\end{array}$ & Rank \\
\hline 1. & $\begin{array}{l}\text { The contexts of economy, poli- } \\
\text { tics, culture and society }\end{array}$ & 4.09 & 14 & 4.12 & 13 & 4.05 & 14 & 4.08 & 4 \\
\hline 2. & The directions of the authorities & 4.24 & 8 & 4.25 & 5 & 4.20 & 7 & 4.23 & 1 \\
\hline 3. & $\begin{array}{l}\text { The coordination of students' } \\
\text { parents }\end{array}$ & 4.20 & 11 & 4.13 & 12 & 4.13 & 12 & 4.16 & 2 \\
\hline 4. & $\begin{array}{l}\text { The coordination of the local } \\
\text { authorities }\end{array}$ & 4.14 & 13 & 4.12 & 14 & 4.09 & 13 & 4.12 & 3 \\
\hline \multicolumn{2}{|c|}{ Overall assessment of external factors } & 4.17 & & 4.16 & & 4.12 & & 4.15 & \\
\hline
\end{tabular}


A strong agreement in evaluation of the three surveyed groups is showed in Table 1 . The three factors which are evaluated at "Quite affected" level are "The contexts of economy, politics, culture and society", "The coordination of students' parents" and "The coordination of the local authorities". Especially, "The direction of the authorities" factor is considered as "Strongly affected" by the three surveyed groups.

The surveyed results has the consistency of the interviewed results that $21 / 21$ principals taking part in the interviews claim that the directions of the authorities has effect on their management activities of changes in schools.

\subsection{Overall results of the survey on the factors} affecting the management of changes in kindergartens and schools in Ho Chi Minh City

Consolidated survey results of the influential levels of the internal and external factors with 2006 principals, vice-principals, subject division-heads, education staffs in kindergartens, primary and secondary schools have classified the factors into 2 groups:

- The group of "strongly affected" factors includes 9 ones which are the ability of principals in managing changes (ranked $1^{\text {st }}$ ), the attitude of principals towards changes (ranked $2^{\text {nd }}$ ), the prestige of the principals in schools (equal ranked $2^{\text {nd }}$ ), the awareness of the importance of managing changes (ranked $4^{\text {th }}$ ), the quality and common sense of education staffs (ranked $5^{\text {th }}$ ), the financial conditions and school facilities (ranked $6^{\text {th }}$ ), the directions of the authorities (ranked $7^{\text {th }}$ ), the ability of education staffs to perform tasks (ranked $8^{\text {th }}$ ), and the attitude of education staffs towards changes (ranked $9^{\text {th }}$ );
- The group of "quite affected" factors includes 5 ones which are the school culture (ranked $10^{\text {th }}$ ), the activities of the Communist Party and other associations (ranked $11^{\text {th }}$ ), the coordination of students'parents (ranked $12^{\text {th }}$ ), the coordination of the local authorities (ranked $13^{\text {th }}$ ), and the contexts of economy, politics, culture and society(ranked $\left.14^{\text {th }}\right)$.

\section{Conclusions}

Firstly, the factors of principals are valued at the highest level of affecting the management of changes in kindergartens and schools. Principals are the subjects who control the changes of in kindergartens and schools. Besides, the factors of principals are the subjective ones affecting their management.

Secondly, among the factors of principals, the management abilties and the attitude towards changes and the prestige are more appreciated than their awareness of the importance of managing changes. Having good awareness is not enough to effectively manage changes. Therefore, principals need to learn the new knowledge and skills of managing changes, improve the qualities and capabilities to enhance their prestige in order to take advantage in leading kindergartens and schools to the innovation successfully.

Finally, there are many internal land external factors affecting the principals' management. Although the direction of the authorities is the external factor, it is still considered as strongly affected. With the directions of the authorities, principals could be given chances to implement changes, however, the changes sometimes are required to be done in the legal frameworks which influence active and creative levels.

\section{References:}

1. Government of the Socialist Republic of Vietnam. (2012). Vietnam Educational development strategy in the period of 2011-2020.

2. Herold D. M., \& Fedor D. B. Change the way you lead change. (Translators: Bui Thanh Chau \& Nguyen Minh Quang). Hanoi: Hong Đuc Publishing House. 2013.

3. Harvard University. Managing change and transition. (Translators: Tran Thi Bich Nga, Pham Ngoc Sau). Hochiminh City: General Publishing House. 2015. 
4. Nguyen Thi Bich Dao. The management of changes in organizations. Journal of Science, Hanoi National University, Economics and Business, 25, 2009. - P. 159-166.

5. Nguyen Thi Thuy Dung. (). The management of changes in schools. Vietnam Journal of Education, 433(1), 2018. - P. 5-7.

6. Vietnam Communist Party. The Resolution of the 8th Plenum of the Central Committee of the Communist Party of Vietnam (XI) on the basic and comprehensive renovation of education and training. 2013.

7. Vietnam Academy of Education Management. The textbook for high school managers, 1(4). Hanoi: University of Education Publishing House. 2013. 